\title{
George Back (1796-1878)
}

George Back, British admiral and arctic explorer, was born in 1796 and joined the Navy in 1808. At the age of thirteen he was wounded, made a prisoner of war, and lodged in the French fortress of Verdun. He passed several years of captivity by devoting himself to the study of drawing and mathematics.

Returning to the Navy in 1818, Back sailed as mate in the Trent, under Lieutenant John Franklin, on an abortive voyage into the Spitsbergen ice. In the following year, his qualifications as artist procured him an appointment on Franklin's first overland expedition to the Polar Sea (1819-1822).

Franklin's party, consisting of five naval personnel and a contingent of Indian hunters and voyageurs from the fur posts, set up base at Fort Enterprise in the wilderness north of Great Slave Lake. Back made a tour of trading stations, canvassing for supplies, but he almost wrecked the expedition by a squalid quarrel with his fellow-midshipman Robert Hood over an Indian woman. In July and August, 1821, with twenty men in two large canoes, they defied ice-pack and gale to map the arctic coast from the mouth of the Coppermine River through and beyond Bathurst Inlet. They started back to their base camp at Fort Enterprise, an overland march made hideous by cold, famine, and suspicions of murder and cannibalism. Hood and half the voyageur escort perished; Franklin, with most of the remainder of the party, lay down starving and helpless at Fort Enterprise. With the strongest men, Back went forward to seek help from the roving Indians. In spite of weakness and hunger, he did not lose heart. Keeping the lagging voyageurs on the march, Back chanced upon Indians who hastened to rescue his comrades. The courage and endurance displayed by Back at that time was a greater service to discovery than any of the later expeditions made under his own command: he saved the lives of Franklin and his surgeon-scientist John Richardson and so preserved the priceless geographical and scientific data gathered by the expedition.

Between 1825 and 1827, Back was second-in-command of Franklin's second overland expedition. The lessons of the costly previous journey had been well learned; with minimum hardships and casualties, the map of the North American Arctic was vastly extended. Nearly half of a previously unknown shoreline was laid down by the two expeditions.

Back took command of a government-aided private expedition in 1833. Its mission was to find the source of the Great Fish (now Back) River, which lay to the north of Great Slave Lake, but was known only by Indian report. Back was to descend the river to the sea and bring aid to the Ross expedition, thought to be lost in Boothia. When the Ross party unexpectedly returned to England before the relief party's departure, Back was directed to explore the coast westward from the river's mouth. By patient groping through rock and bush, he found the source of the river in tiny Sussex Lake, and in a boat fashioned by ship's carpenters from the primeval forest, Back, accompanied by Dr. Richard King and Scottish servants of the Hudson's Bay Company, overcame the obstacles of partially frozen lakes and chafing rapids to explore the long and turbulent watercourse to its mouth. There he was forced by pack ice to end his journey. Except in a crisis, Back was prone to be slack and self-indulgent, and on his return home he was publicly censured by Dr. King for sloth, poor discipline, and lack of enterprise.

In the years 1836-37, Back commanded H.M.S. Terror on a cruise into northern Hudson Bay. The ship was beset and drifted for months in bitter cold, heaved up on a mound of ice. When this frozen platform collapsed, the ship was nearly capsized into the waters of the bay, but she escaped with numerous leaks and a badly wrenched keel to reach a home port. On this cruise, the captain seems to have depended on his competent first lieutenant, as he had formerly depended on the industrious Dr. King. The fiasco was no fault of Back's, but his health was broken, and although he remained on the active list and attained the rank of admiral, he was never again employed afloat. He served on the Arctic Council, which directed the Franklin search, and in extreme old age was appointed to unveil the Franklin monument in Westminster Abbey.

In Back, the "gentleman" predominated over the "officer". He managed his Fish River boat crew with tact, but he exasperated the factors of the fur trade - who professed to be his equals and whom he ought to have made a point of conciliating - by his conceit and patronizing airs. On the other hand, his aptitude for dialects permitted him to fraternize with Metis, Indian, and Eskimo: he relished posing as a "great chief". But he was not a "great captain". His qualities of courage, of endurance, and of resource in calamity were best displayed in a subordinate capacity under Franklin. Nevertheless, he gave "colour" to his sphere of life by his numerous adventures and by his manner of recording them. He shows humour and good-fellowship in recounting his tippling bout with Indians and how his guide wormed brandy out of him as medicine. He had the artist's eye for scenery; his descriptions of the panorama at Portage La Loche, of the fire-scarred landscape at Artillery Lake, and of the descent of boiling rapids on the Great Fish River have an instant appeal to those who know the North. In natural and effortless prose, he depicts the crew's breathless suspense when the Terror listed till her lee boats touched the water and she "trembled on the brink of eternity". He has a special claim on the regard of Canadians as a pioneer of the North and as a prose artist who has described its landscapes and peoples with love and understanding.

\section{FURTHER READINGS}

BACK, GEORGE. 1838. Narrative of an Expedition in H.M.S. Terror, 1836-37. London: John Murray.

1970. Narrative of the Arctic Land Expedition. Reprinted Edmonton: M.G. Hurtig. (Originally pub. 1836).

FRANKLIN, JOHN. 1969. Narrative of a Second Expedition to the Polar Sea. Reprinted New York: Greenwood Press. (Originally pub. 1828). 1970. Narrative of a Journey to the Shores of the Polar Sea. Reprinted Edmonton: M.G. Hurtig. (Originally pub. 1828).

NEATBY, L.H. 1970. Search for Franklin. Edmonton: M.G. Hurtig. 1958. In Quest of the Northwest Passage. Toronto: Longmans, 


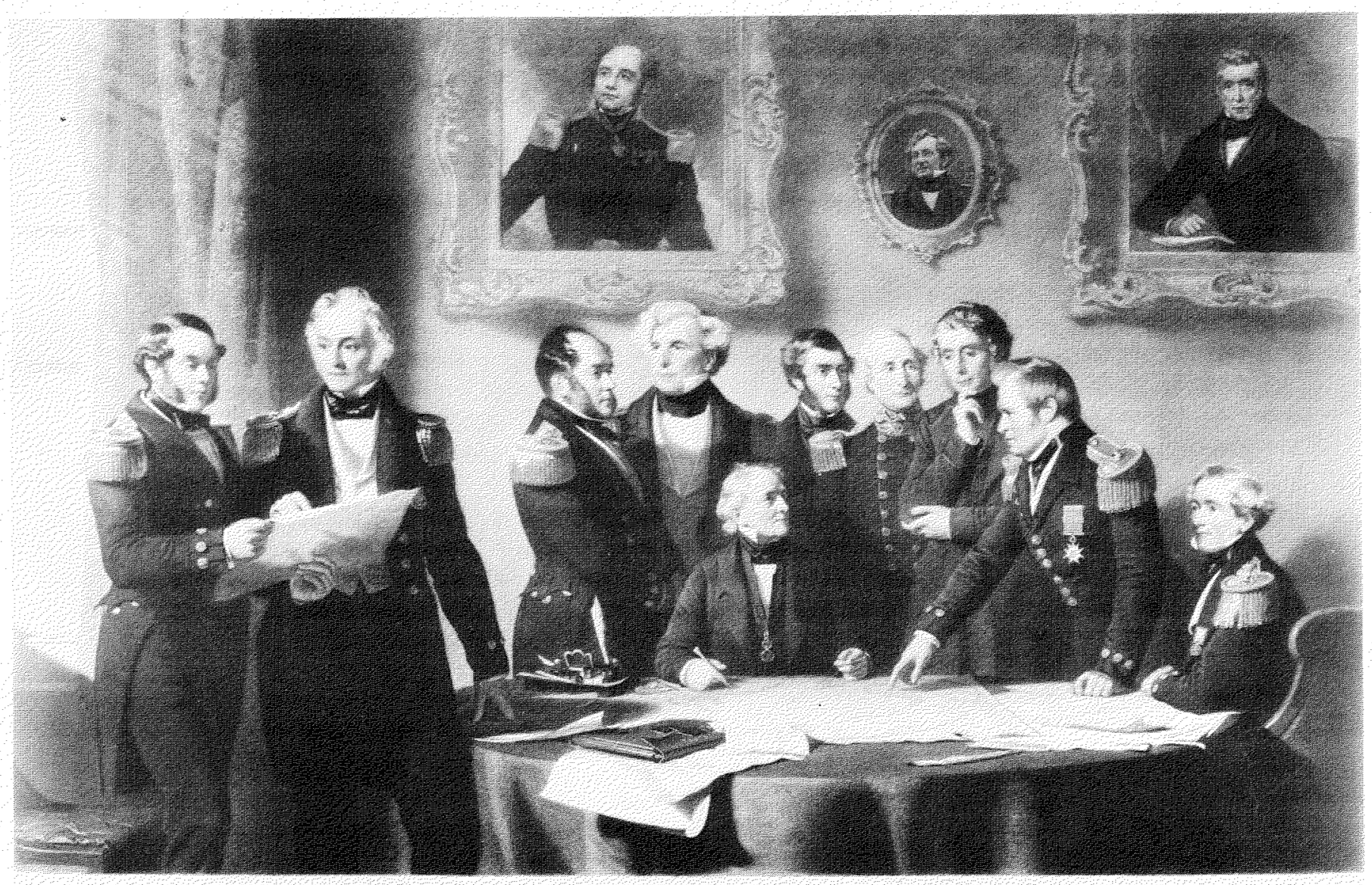

The Arctic Council, 1845, Discussing the Plan of Search for Sir John Franklin. Painted by Stephen Pearce, engraved by James Scott. Reproduced courtesy of Royal Ontario Museum. George Back is at extreme left. 